\title{
The Importance Of Earnings Forecasts, Sales Forecasts, And Cash Flow Forecasts To Stock Price Forecasts Of Internet Companies
}

Mehdi Sheikholeslami, (msheikho@uwec.edu), University of Wisconsin-Eau Claire

\begin{abstract}
The spectacular rise and fall of internet company stock values has called into question the rationality of the traditional earnings-based valuation models for internet companies. Unlike many "old-economy" companies with stable revenue and earnings streams, internet companies often exhibit little current revenues and substantial negative earnings, yet they command very high prices. One plausible explanation for this phenomenon is that the value of internet companies is driven by the expected future growth opportunities. Accordingly, this paper examines the relative importance of sales forecasts, cash flow forecasts, and earnings forecasts to stock price forecasts of internet companies. As predicted, only cash flow forecasts and sales forecasts are significantly associated with stock price forecasts. That is earnings forecasts are not relevant to stock price predictions of internet companies.
\end{abstract}

\section{Introduction}

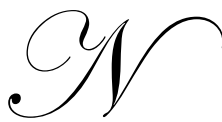

o doubt the advent of the internet in mid 1990s has revolutionized communications and commerce and thereby contributed to the recent productivity gains and economic growth in the U.S. (IIE Solutions, 2001). However, while consumers have benefited from this new technology the internet company investors have not fared as well. In fact these days one can buy most internet stocks at $90 \%$ (or more) discount to recent highs. The observed drastic decline in internet company stock values has called into question the rationality of the traditional earnings-based valuation models for internet companies (Lev, 2001). Unlike many "old-economy" companies with stable revenue and earnings streams, internet companies often exhibit little current revenues and substantial negative earnings, yet they command very high prices. The most plausible explanation for this phenomenon is that the value of internet companies is driven by the expected future growth opportunities (Ottoo, 2000). Accordingly this paper investigates the relative importance of projected revenues, projected cash flows, and projected earnings in the valuation of internet company stocks.

\section{Review of Internet Studies}

The value relevance research in accounting empirically examines the association between market value of a security (dependent variable) and a set of independent accounting measures (Beaver, 2002). While the valuation of internet stocks is the hottest topic in professional and academic circles, surprisingly only few published studies empirically evaluate the accounting drivers of value for internet companies. Trueman et al (2000) report no significant relationship between earnings and market values. However, when earnings is decomposed into gross profit, marketing expenditure, R\&D expenditure and other expenditure, gross margin becomes positively and significantly associated with market value of e-tailers. Graham et al (2002) choose earnings and book values in their research. They re

Readers with comments or questions are encouraged to contact the author via email. 
port no significant association between earnings and market values but positive and significant association between book values and market values of internet companies.

Bartov et al (2002) employ the most comprehensive set of accounting measures (earnings, cash flows, sales, sales growth, and book values) to evaluate the pricing of internet IPOs. They also employ a ( non-internet IPO) control sample. They document noticeable differences in IPO valuation between internet and non-internet firms. They report that non-internet firm IPO prices are based on positive earnings and positive cash flows while internet IPO firm prices are not associated with earnings, but are associated with cash flows.

\section{Conceptual Model}

For more than 30 years, accounting and finance researchers have examined the relation between accounting variables (especially earnings) and stock prices (e.g., Ball and Brown, 1968). Much is known about the information content of realized earnings for ex post prices. For example, earnings are more important than cash flows for equity valuation (Barth et al, 2001). However, little is known about the relevance of forecasted accounting variables for forecasted stock prices. This issue is particularly relevant to internet companies for several reasons. First, internet industry is very young and as such sufficient historical financial data are not available. Second, the internet industry is highly intangible-asset intensive and as such earnings numbers are not reliable (current accounting standards require immediate expensing of all marketing investments and R\&D outlays which understates earnings). Third, heavy use of stock options by internet companies without proper accounting distorts earnings. Finally, and perhaps most significant, internet industry is evolving fast and most future growth may come from products the industry has not identified yet (Milano, 2001). For these reasons the past and current financial performance of internet companies may not be a good indicator of current and/or future stock values. Accordingly, the main objective of this paper is to determine which forecasted accounting variable is most relevant to internet stock valuation. We include sales forecast, cash flow forecast and earnings forecasts in our empirical tests. To the extent future growth opportunities are due to intangibles assets, proceeds from future sales may flow to providers of those assets (e.g., bonuses and stock options for key personnel) and not the shareholders. Thus sales forecast may not be the most relevant accounting variable. Inadequate accounting standards and/or purposeful manipulation by management can render earnings non-relevant too. However, cash flows are not affected by accounting standards and are less susceptive to manipulations by management. Accordingly, we expect cash flows to be the most relevant accounting variable in internet stock valuation.

\section{Sample and Data}

To our knowledge, the Value Line Investment Survey (Survey), a publication of Value Line, Inc (VL) is the only source that provides both short-term and long-term sales forecasts, cash flow forecasts and earnings forecasts. The Survey also provides current prices and long-term price forecasts. VL analysts predict sales, cash flow, earnings and stock prices on a quarterly basis for all 1700 companies covered by the Survey. Once every 13 weeks, VL analysts forecast a firm's sales, cash flow and earnings for the current year, the next year, and 3-5 years in advance along with a stock price range for 3-5 years ahead. We take the midpoint of the VL analyst's stock price range forecast and relate it to his sales forecast, cash flow forecast, and earnings forecast over the same time horizon (three to five years).

Our sample includes all internet companies covered by the Survey from September 1999 to November 2001 (total of 10 quarters) which resulted in 150 firm-quarter observations. Following Bartov et al (2002) we also employ a control sample of non-internet (food processing) companies. We expect dissimilar value drivers across the two samples. 


\section{Statistical Model}

The main purpose of this paper is to identify the most important accounting value drivers of the internet and food processing company stock prices. Accordingly, we regress the change in stock price forecasts on the change in sales forecasts, change in cash flow forecasts, and change in earnings forecasts of sample companies using the following regression equation:

$$
\Delta \text { PRICE }=\mathrm{a}_{0}+\mathrm{a}_{1} \Delta \text { SALES }+\mathrm{a}_{2} \Delta \mathrm{CASH}+\mathrm{a}_{3} \Delta \text { EARN }+ \text { error }
$$

Where:

$$
\begin{aligned}
& \Delta \text { PRICE }=(\text { Future price }- \text { Current price }) / \text { Current price } \\
& \Delta \text { SALES }=(\text { Future sales }- \text { Current sales }) / \text { Current price } \\
& \Delta \text { CASH }=(\text { Future cash flow }- \text { Current cash flow }) / \text { Current price } \\
& \Delta \mathrm{EARN}=(\text { Future earnings }- \text { Current earnings }) / \text { Current price }
\end{aligned}
$$

Future price is the midpoint of 3-5 year share price forecast. Current price is the recent share price reported in the Survey. Future sales, future cash flow, and future earnings are 3-5 year (per share) forecasts. Current sales, current cash flow, and current earnings are current year (per share) forecasts. To control for heteroscedasticity, all variables are deflated by current price (Christie, 1987).

\section{Empirical Results}

Table 1 provides descriptive statistics for undeflated variables for internet and food processing samples. Table 1 also presents parametric and nonparametric tests of the differences in the means between the two samples.

TABLE 1: Descriptive Statistics (Undeflated)

\begin{tabular}{l|cccccc}
\hline \multirow{2}{*}{ Variable } & \multicolumn{2}{|c}{ Internet $(\mathbf{n}=\mathbf{1 5 0})$} & \multicolumn{2}{c}{ Food Processing $(\mathbf{n}=150)$} & \multicolumn{2}{c}{ Difference } \\
\cline { 2 - 7 } & Mean & St. Dev. & Mean & St. Dev & t-stat & Z-stat $^{1}$ \\
\hline$\Delta$ PRICE & 51.1029 & 58.3280 & 20.1234 & 10.7568 & $-6.397^{*}$ & $-6.507^{*}$ \\
$\Delta$ SALES & 7.1320 & 5.5169 & 12.0121 & 8.8148 & $5.748^{*}$ & $-6.046^{*}$ \\
$\Delta$ CASH & 2.2223 & 1.3297 & 1.5004 & .7434 & $-5.804^{*}$ & $-5.185^{*}$ \\
$\Delta$ EARN & 2.1799 & 1.7154 & 1.1612 & .5374 & $-6.940^{*}$ & $-6.631^{*}$ \\
\hline
\end{tabular}

${ }^{\mathrm{I}} \mathrm{Z}$ statistic is computed using Mann-Whitney test.

* Significant at .001 level.

Table 1 clearly indicates that internet companies are expected to have significantly larger stock price increase ( $\triangle$ PRICE), more cash flow increase ( $\triangle \mathrm{CASH})$, and more earnings

( $\triangle$ EARN) increase than food processing companies. But, surprisingly, Table 1 also indicates that increase in sales ( $\triangle$ SALES) is expected to be much larger for food processing than for internet companies. The most plausible explanation for this observation is that VL analysts expect larger sales growth but much lower profit margin growth for food processing sample as compared to internet sample.

Table 2 reports pair-wise correlations between all variables used in the regression. Panel A of Table 2 presents correlation coefficients for internet sample. Consistent with expectations the results from Panel A indicates that internet company stock price ( $\triangle$ PRICE) is positively and significantly correlated with cash flow ( $\Delta$ CASH) only. Panel B of Table 2 on the hand reveals that food processing company stock price is positively and significantly correlated with all three accounting variables. 
TABLE 2: Pearson Correlation Coefficients (Undeflated)

(p-values in parentheses)

\begin{tabular}{|c|c|c|c|c|}
\hline \multicolumn{5}{|c|}{ Panel A. Internet } \\
\hline & $\triangle$ PRICE & $\triangle$ SALES & $\triangle$ CASH & $\triangle$ EARN \\
\hline \multicolumn{5}{|l|}{$\triangle$ PRICE } \\
\hline$\triangle$ SALES & $\begin{array}{c}.029 \\
(.721)\end{array}$ & & & \\
\hline$\triangle \mathrm{CASH}$ & $\begin{array}{l}.217 * * \\
(.008)\end{array}$ & $\begin{array}{l}.336 * * \\
(.000)\end{array}$ & & \\
\hline$\Delta$ EARN & $\begin{array}{c}.121 \\
(.141)\end{array}$ & $\begin{array}{l}.164 * \\
(.045)\end{array}$ & $\begin{array}{l}.732 * * \\
(.000)\end{array}$ & \\
\hline \multicolumn{5}{|c|}{ Panel B. Food Processing } \\
\hline & $\triangle$ PRICE & $\triangle$ SALES & $\triangle$ CASH & $\triangle$ EARN \\
\hline \multicolumn{5}{|l|}{$\triangle$ PRICE } \\
\hline$\triangle$ SALES & $\begin{array}{l}.477 * * \\
(.000)\end{array}$ & & & \\
\hline$\triangle \mathrm{CASH}$ & $\begin{array}{l}.570 * * \\
(.000) \\
\end{array}$ & $\begin{array}{l}.744 * * \\
(.000) \\
\end{array}$ & & \\
\hline$\Delta$ EARN & $\begin{array}{l}.585 * * \\
(.000)\end{array}$ & $\begin{array}{l}.692 * * \\
(.000)\end{array}$ & $\begin{array}{l}.927 * * \\
(.000)\end{array}$ & \\
\hline
\end{tabular}

** Significant at .001 level

Furthermore, both Panels A and B of Table 2 show positive and significant correlations among all three accounting variables. However, correlation coefficients are much stronger for the food processing sample which may indicate more stable and predictable operations in the food industry verses the internet industry.

Table 3 presents the results from the OLS regression of the change in price on change in accounting variables for both samples (internet and food processing). The internet sample results are consistent with prior internet studies; the coefficient on earnings ( $\triangle \mathrm{EARN}$ ) is insignificant. Our results suggest that internet company stock prices are positively and significantly associated with cash flows and sales.

For food processing sample, stock price ( $\triangle$ PRICE) is positively and significantly associated with sales ( $\triangle$ SALES) and cash flow ( $\Delta$ CASH), but negatively and significantly associated with earnings ( $\triangle$ EARN). This result is most likely due to population-inherent multicollinearity (Gunst and Mason, 1980). For example, panel B of Table 2 shows almost perfect correlation (coefficient of .972) between cash flow ( $\triangle \mathrm{CASH}$ ) and earnings ( $\triangle$ EARN); which implies that for food processing companies, information content of earnings is identical to information content of cash flows. As such inclusion of redundant variables may cause regression coefficients become unstable and show opposite signs. Multicollinearity, however, does not diminish the predictive power of the regression model (Gunst and Mason, 1980). 
TABLE 3: OLS Regression Results of Change in Price on Change in Accounting Variables (deflated) (t-statistics in parentheses)

\begin{tabular}{l|cc}
\hline \hline & $\begin{array}{c}\text { Internet } \\
(\mathbf{n = 1 5 0 )}\end{array}$ & $\begin{array}{c}\text { Food Processing } \\
(\mathbf{n = 1 5 0 )}\end{array}$ \\
\hline Intercept & $1.364^{* *}$ & $.391^{* *}$ \\
& $(8.122)$ & $(4.550)$ \\
\hline SALES & $.386^{*}$ & $.333^{*}$ \\
& $(2.331)$ & $(1.974)$ \\
\hline CASH & $4.439^{* *}$ & $9.162^{* *}$ \\
& $(4.395)$ & $(4.469)$ \\
\hline Edjusted R & $-1.935 \mathrm{e}^{-2}$ & $-5.014^{* *}$ \\
\hline S Signican & $(-.033)$ & $(-3.212)$ \\
\hline
\end{tabular}

* Significant at .05 level

** Significant at .01 level

\section{Conclusion}

We examine the association between accounting variables and stock prices of a sample of internet companies and a control sample of food processing companies. Our main objective is to determine the most important accounting value drivers of internet company stock prices and whether the value drivers differ between the two samples.

Our results indicate that the food processing company stock price valuation follows conventional wisdom: expected growth in sales, cash flows and earnings are all important. The valuation of internet company stock price, however, departs from conventional wisdom, with earnings not being important and only cash flows and sales are being relevant.

\section{References}

1. Ball, R., and P. Brown. "An Empirical Evaluation of Accounting Numbers," Journal of Accounting Research, 6, 19-178, 1968.

2. Barth, M., D. Cram, and K. Nelson. "Accruals and the Prediction of Future Cash Flows," The Accounting Review, 76, 27-58, 2001.

3. Bartov, E., P. Mohanram, and C. Seethamaraju. "Valuation of Internet Stocks- An IPO Perspective," Journal of Accounting Research, 40, 321-346, 2002.

4. Beaver, W. "Perspectives on Recent Capital Market Research," The Accounting Review, 77, 453-474, 2002.

5. Christie, A. "On Cross-sectional Analysis in Accounting Research," Journal of Accounting and Economics, 9, 231-258, 1987.

6. Graham, C., M. Cannice, and T. Sayre. "The Value Relevance of Financial and Non-financial Information for Internet Companies," Thunderbird International Business Review, 44, 47-70, 2002.

7. Gunst, F., and R. Mason. Regression Analysis and its Application. New York: Marcel Deckker, 1980.

8. IIE Solutions. "Internet Increases Productivity," IIE Solutions, 33, 14, 2001.

9. Lev, B. Intangibles: Management, Measurement, and Reporting, Washington, D.C.: Brookings Institution, 2001.

10. Milano, G. "EVA and the "New Economy"," Bank of America Journal of Applied Corporate Finance, 13, 118-128, 2000.

11. Ottoo, R. Valuation of Corporate Growth Opportunities: A Real Options Approach, New York: Garland Publishing, 2000.

12. Trueman, B., M. H.F. WONG, and X. J. Zhang. "The Eyeballs Have it: Searching for the Value in Internet Stocks," Journal of Accounting Research, 38, 137-162, 2000. 
Notes 